\title{
PENGEMBANGAN PEMBIBITAN DAN PENGENDALIAN PRODUKSI PETERNAKAN AYAM KAMPUNG DI PINGGIRAN KOTA MALANG
}

\author{
Dedi Suryanto', Irawati Dinasari ${ }^{2}$ dan Usman $\mathrm{Ali}^{3}$ \\ ${ }^{1}$ Fakultas Peternakan Universitas Islam Malang \\ email: dedi suryanto@unisma.ac.id \\ ${ }^{2}$ Fakultas Peternakan Universitas Islam Malang \\ email: irawati.dinasari12@yahoo.com \\ ${ }^{3}$ Fakultas Peternakan Universitas Islam Malang \\ email: usmanchalim@gmail.com
}

\begin{abstract}
ABSTRAK
Program Iptek bagi masyarakat ini bertujuan untuk mengembangkan pembibitan dan pengendalian produksi ayam kampung dalam berbagai aspek sapta usaha peternakan terutama manajemen pembibitan, pengendalian produksi, strategi pemberian pakan, bioteknologi pakan, reboisasi tanaman pangan dan sistem pemasaran. Metode yang digunakan adalah observasi, penyuluhan, demo plot, pembinaan dan pendampingan di lapang. Hasil program IbM ini menunjukkan bahwa respon peternak baik sekali dan proaktif dalam semua kegiatan baik selama penyuluhan, pembinaan, demo plot dan pendampingan. Sistem pembibitan ayam kampung sudah intensif dengan kandang panggung atas bawah berdinding bambu, menggunakan pakan komersial dan vaksinasi pengobatan penyakit sudah terprogram. Kandang pembibitan dengan perbandingan jumlah betina dan pejantan $=5: 1$ dan lama penetasan berkisar antara 21-23 hari dengan daya tetas telur diatas $85 \%$. Pemeliharaan ayam final stock siap potong selama 3 - 4 bulan dilakukan oleh peternak binaan. Peternak masih menggunakan pakan komersial harga mahal dan jalur pemasaran ayam kurang luas terutama konsumen perumahan dan warung khusus. Kesimpulan program IbM ini yaitu peternak sudah melakukan sistem pembibitan dan pengendalian produksi peternakan secara intensif. Disarankan penggunaan limbah warung nasi untuk pengganti jagung dan bekatul yang diformulasi dengan konsentrat sebagai pakan komplit.
\end{abstract}

Kata kunci: Pembibitan, peternakan intensif, ayam buras.

\section{PENDAHULUAN}

\section{Kondisi Mitra}

Usaha pembibitan dan peternakan ayam kampung milik mitra usaha ini sudah menggunakan sistem intensif, dimana unggas dikandangkan secara koloni dan kandang bersekat. Pemberian pakan sudah menggunakan pakan komersial dibeli di poultry shop denganharga mahal dan fluktuatif yang pasti memberatkan peternak. Pada awalnya mitra pernah membuat campuran pakan sendiri, namun dengan kendala pengadaan bahan pakan susah 
sehingga stoks bahan baku pakan sering tidak mencukupi kebutuhan ayam, selain itu kualitas pakan rendah karena pakan yang diberikan seadanya dan tidak diformulasikan dengan benar, sehingga kandungan nutriennya tidak sesuai standart kebutuhan bagi unggas. Ayam kampung sebagai unggas lokal mempunyai banyak potensi yaitu daya tahan tubuh baik dan adaptif, cepat berkembangbiak, bobot hidup dan karkas lebih mahal dibanding ayam ras serta produk ayam kampung baik telur dan dagingnya disukai konsumen. Lebih lanjut ayam kampung sebagai hewan omnivora pemakan segala bahan pakan sehingga pemberian pakannya mudah dan menyukai bahan pakan nabati maupun hewani. Dengan demikian perlu adanya pemanfaatan limbah warung nasi dan limbah agroindustri lokal sebagai pakan ayam kampung sekaligus perbaikan manajemen pemeliharaan yang intensif sehingga usaha peternakan ini berpeluang sebagai bisnis terpadu yang menguntungkan.

Peternakan ayam kampung ini berlokasi di pinggiran dan perbatasan kota Malang, tepatnya peternak breeder pembibit ayam kampung berada di Kelurahan Tlogomas, Lowokwaru Kota Malang, sedangkan peternak binaan di Desa Mulyoagung, Kecamatan DAU, Kabupaten Malang. Peternakan ini berdekatan dengan pemukiman padat penduduk terutama masyarakat pendatang yakni mahasiswa berbagai perguruan tinggi seperti Universitas Muhammadiyah Malang, Universitas Tri Bhuana Malang dan Sekolah Tinggi IImu Administrasi Malang. Apabila tidak dikelola dengan baik dapat menimbulkan bau kurang sedap yang mencemari lingkungan dan masyarakat sekitar merasa kurang nyaman dan rawan akan mengusiknya. Lokasi ini juga dilintasi jalan aspal menuju pemandian wisata Sengkaling, Jatim Park, dan Museum Satwa Batu Malang sehingga jangkauan lalulintas mudah dan banyak wisata kuliner berarti banyak bermunculan rumah makan, cafetaria dan warung nasi yang tentu menghasilkan limbah organik yang berpotensi sebagai pakan ayam, namun belum banyak dimanfaatkan peternak. Pada awalnya pemeliharaan unggas kampung milik mitra ini hanya sebagai usaha sambilan dan tabungan hidup dengan manajemen pemeliharaan dan pemberian pakan amburadul sehingga produktifitas rendah dan dibiarkan liar tidak dikandangkan sehingga rentan terkena penyakit. Dengan seringnya kelangkahan bibit ayam kampung, maka pada tahun 2004 Mas Agus Prayudi berinisiatif mengembangkan aspek pembibitan ayam kampung unggul. Tokoh ini menggeluti penetasan dan pembibitan penghasil bibit ayam kampung dan membentuk peternak binaan.

Tim pengabdi melakukan observasi pada April 2012 menunjukkan bahwa kondisi breeder dan usaha peternakan ayam kampung berkembang pesat, telah mempunyai 4 cabang breeder dan dalam masa inkubasi penetasan menghasilkan anakan ayam umur sehari sebanyak 425 ekor dan telah merangkul lebih dari 45 peternak ayam kampung yang menjadi binaannya. Selain itu breeder ini menampung panenan ayam kampung siap potong dari peternak binaannya dan mengembangkan pemotongan ayam kampung dipasarkan berupa karkas untuk didistribusikan kirim langsung ke konsumen 
warung soto dan permintaan insidental masyarakat perumahan melalui telpon Hand phone, dll.

\section{Aspek Produksi dan ManajemenUsaha Mitra}

Secara umum pemeliharaan ayam kampung milik pembibit dan peternak binaan sudah memperhatikan dan pengendalian aspek produksi dalam panca usaha peternakan yang meliputi pemilihan bibit dan penetasan, pemberian pakan, pemeliharaan dan perkandangan, pencegahan penyakit dan pemasaran sudah dilakukan dengan baik, walau ada beberapa faktor yang belum dikuasai dengan benar. Hal inilah yang menjadi permasalahan yang dihadapi kelompok peternak ayam kampung di pinggiran Kota Malang dan segera dicari solosinya bersama dengan tim pengabdi program $\mathrm{I}_{b} \mathrm{M}$ Universitas Islam Malang.

Manajemen usaha mulai model kandang sistem bertingkat atas bawah, dinding terbuat dari sebagian tembok dan rangka kayu dan belahan bambu berjajar bercela sebagai sisi depan dan samping, atap asbes bergelombang dan bagian dinding yang tidak rapat sehingga kandang tidak panas dengan kelembaban yang tepat. Alas kandang menggunakan litter pasir yang dicampur sedikit kapur dan sekam padi dengan ketebalan 10-15 Cm untuk menghangatkan tubuh ayam dan setiap 4-5 bulan sekali alas kandang ini diganti dengan litter baru untuk menghindari timbulnya penyakit. Litter yang lama dibuang atau dibakar saja, seharusnya litter ini digunakan sebagai bahan kompos untuk pupuk organik yang murah dan menyuburkan tanaman.

Jumlah pejantan dan induk ayam kampung dalam setiap petak kandang pembibitan rasio $1: 5$, dengan pejantan Bangkok dan betina ayam Kedu atau ayam Arab dengan sanitasi kandang cukup baik, sedangkan pada tingkat peternak binaan masih kurang memperhatikan kebersihan kandang yang sering berakibat terkena penyakit yang menimbulkan kematian. Pakan yang diberikan berupa pakan komersiel produksi Japfa Comfeed sehingga memakan biaya pakan yang mahal dan sering tercecer.Demikian pula pada peternakan binaan telah disarankan oleh pembibit untuk menggunakan produk pakan komersiel dengan alasan segi praktis dan tanpa resiko. Hal ini berakibat biaya pakan mahal, disisi lain modal para peternak binaan terbatas, maka tim pengusul IbM ini akan memberikan solusi mengatasi mahalnya biaya pakan dengan mencari dan menggunakan pakan alternatif yang telah diformulasi sesuai dengan standart kebutuhan nutrisi bagi ayam. Program vaksinasi sudah di peternak breeder sudah dilaksanakan dengan baik mengikuti petunjuk suplayer obat-obatan ayam Medion atau poultry shop dan lainnya. sedangkan ditingkat peternak binaan masih amburadul. Dari sisi ekonomis, keberadaan mitra usaha peternakan ayam kampung ini banyak menyerap tenaga kerja yang dapat mengurangi pengangguran di pedesaan serta mendatangkan banyak keuntungan bagi peternak, harga jual ayam kampung siap dipotong umur 2 sampai 3 bulan berbobot sekitar $0,8 \mathrm{~kg}$ sampai 1 kg berkisar Rp. 28000 sampai Rp. 40000,. 


\section{Permasalahan Mitra}

Tim pengabdi setelah melakukan observasi ke lokasi dan wawancara dengan pemilik mitra usaha peternakan, maka permasalahannya dapat diidentifikasi sebagai berikut:

\section{Mitra I: Pembibitan ayam kampung (Breeder)}

- Mitra ini masih belum dapat memenuhi permintaan DOC ayam kampung anggota peternak binaan lebih dari 45 peternak, perlu tambahan mesin tetas

- Imbangan jantan betina rendah (5:1) dalam kandang pembibitan, rasio ini perlu ditingkatkan menjadi rasio 1:10 (Rasyaf, 1993)

- Kapasitas mesin tetas perlu ditingkatkan dan ditambah jumlahnya.

- Produktifitas telur ayam kampung masih rendah, namun pertumbuhan ayam optimal dengan nilai konversi pakan sebesar 2,4 mendekati standar ayam pedaging (broiler) di bawah nilai 2 .

- Biaya pakan mahal, karena menggunakan pakan komersial produksi Japfa Comfeed(Rp. 195.000,/ zak 50 kg), perlu menggunakan pakan alternatif yang bergizi cukup dan terjamin.

- Jumlah pemberian pakan kurang baik secara ad libitum dalam kotak pakan tetapi jarang dikontrol sehingga pakan banyak tercecer.

- Pemilihan indukan ayam kedu dan ayam arab yang tidak mengeram sehingga bertelur terus, sedang ayam pejantan keturunan bangkok berbadan kekar bukan tipe aduan sehingga anakannya mempunyai pertumbuhan cepat. Hal ini perlu dipertahankan atau mencari persilangan ayam lain sehingga diciptakan ayam kampung yang berproduksi sesuai harapan.

- Kandang masih kotor dan timbul bau kurang sedap terutama musim hujan

- Penanganan penyakit dan vaksinasi kurang tertib

- Menerima penjualan ayam siap potong

- Pemotongan ayam dan pemasaran karkas ayam

\section{Mitra II: Peternak ayam kampung (Farming)}

- Kandang dan litter masih kotor, perlu penggantian litter terprogram

- Kapasitas kandang dari fase starter ke fase finisher kurang diperhatikan

- Masih menggunakan pakan komersial yang harganya mahal, perlu mencari pakan alternatif yang murah dan cukup bergizi sesuai standart kebutuhan nutrisi ayam kampung.

- Proses culling pada ayam yang cacat dan pertumbuhan lambat tidak dilakukan

- Belum ada upaya reboisasi tanaman pohon di sekitar kandang untuk kenyaman suplai oksigen dalam kandang dan menjaga suhu dan kelembaban udara.

- Kesehatan kurang diperhatikan dan mortalitas lebih 15\% sehingga perlu vaksinasi terprogram. 
- Modal usaha kecil dan kadang pinjam bank harian dengan bunga tinggi, apabila panenannya jelek maka akan bangkrut dan berhenti beternak.

- Peternak masih kerja sambilan sebagai buruh tani dan kuli bangunan

- Masih menggunakan tranportasi sepeda pancal sehingga kurang layak

- Penanganan panen dan penjualan ayam siap potong

\section{TARGET DAN LUARAN}

Target program IbM ini adalah tim pengabdi dapat mengembangkan pembibitan ayam kampung milik breeder lokal dan peternak mitra dapat mengendalikan produksi peternakan ayam kampung secara intensif didasarkan pedoman sapta usaha peternakan meliputi penggunaan bibit unggul, pemberian pakan yang cukup gizi dan kuantitasnya, manajemen kandang dan produksi yang baik, sistem pembibitan ayam yang baik, pencegahan dan pengobatan penyakit teratur dan pemasaran tepat sasaran sehingga pendapatan peternak meningkat.

Luaran program IbM ini yaitu model pengembangan pembibitan dan pengendalian produksi peternakan ayam kampung, paket teknologi pakan fermentasi sebagai campuran pakan, mesin tetas dan kandang pembibitan. Selain itu jasa konsultasi penetasan, pembibitan dan sistem pemasaran produk mitra.

\section{METODE PELAKSANAAN}

\section{Metode pendekatan untuk realisasi program $I_{b} M$}

Upaya untuk merealisasikan program $\mathrm{I}_{b} \mathrm{M}$, tim pengabdi menggunakan beberapa metode pendekatan yaitu observasi ulang dan wawancara dengan peternak, melakukan penyuluhan menurut petunjuk Mardikanto (2009), demoplot, pelatihan serta pendampingan selama 2 bulan terakhir dalam masa kerja pelaksanaaan program IbM.

\section{Kegiatan sebagai langkah-langkah solusi atas permasalahan}

Tim pengabdi program lbM telah membuat daftar kegiatan sebagai langkah-langkah solusi atas permasalahan yang dihadapi peternak yaitu:

- Melakukan observasi ke lokasi mitra dan wawancara sambil berdiskusi untuk memperjelas permasalahan yang dihadapi mitra usaha.

- Memberikan penyuluhan tentang keseluruhan aspek produksi pemeliharaan ayam kampung meliputi pembibitan dan penetasan telur, seleksi calon indukan dan pejantan yang unggul, formulasi pakan dan strategi pemberian pakan, program vaksinasi ayam, penanganan panen/ produksi dan pemotongan ayam, analisa usaha dan sistem pemasaran yang menguntungkan.

- Menambah jumlah mesin tetas dengan kapasitas lebih dari 500 telur bibit 
- Pengadaan seperangkat mesin giling/ hammer mill untuk grinding bahan pakan ukuran yang kasar menjadi halus sehingga memudahkan homoginitas campuran pakan.

- Penyediaan bibit tanaman pohon yang produktif seperti pohon nangka, pepaya, muris dan mangga dan melakukan reboisasi massal tanaman tersebut di sekitar kandang.

- Melakukan pelatihan formulasi penyusunan ransum, demoplot pengawetan bahan pakan dari limbah agroindustri digiling dan difermentasi untuk campuran pakan ayam dengan standar nutrisi pakan sebagai berikut: finisher $\mathrm{PK}=18-21 \%$, EM $=3100-3200$ $\mathrm{Kkal} / \mathrm{kg}, \mathrm{SK}=4$ sampai 5,50 \%, LK= $6-8 \%$ (Ensminger, Oldfield dan Heinemann, 1995).

- Penanganan kotoran ayam untuk pengomposan pembuatan pupuk organik

- Mendampingi dan berdiskusi dengan peternak tentang pemeliharaan ayam menuju peternakan intensif dan professional.

- Melakukan culling pada pejantan dan induk yang cacat, tidak normal dan tidak unggul untuk menghindari perkawinan yang tidak dikehendaki.

- Membuat rekording hasil penetasan dan pemasaran atau pendistribusian DOC kepada peternak binaan sekaligus produktifitas ayam selama pemeliharaan.

- Mengatur kepadatan kandang, dimana standart per $m^{2}$ luas kandang di daerah panas 8-10 ekor ayam.

- Memodifikasi alat pencabut bulu dalam penanganan karkas ayam dipotong

- Melakukan analisa usaha peternakan dan ditambah diskusi lingkup pemasaran karkas ayam yang memberi keuntungan.

\section{HASIL DAN PEMBAHASAN}

\section{Persiapan pelaksanaan program IbM}

Sebelum pelaksanaan program IbM ini, tim pengabdi mempersiapkan semua bahan material termasuk pengadaan peralatan yang dibutuhkan untuk realisasi kegiatan yang sudah dirancang dalam proposal. Pengadaan bahan pakan, konsentrat dan pakan komersial dibeli di Poultry shop (Gambar 3), becak motor dimodifikasi dari bagian belakang becak dibuang dan roda depan sepeda motor dipotong, kemudian keduanya dirangkai dengan pipa besi sedemikian rupa dan menggunakan pelek sepeda motor sehingga ketinggian becak merata dan mudah disetir, teknis prosedur merangkai becak motor disajikan pada Gambar 1, 2, 13. 


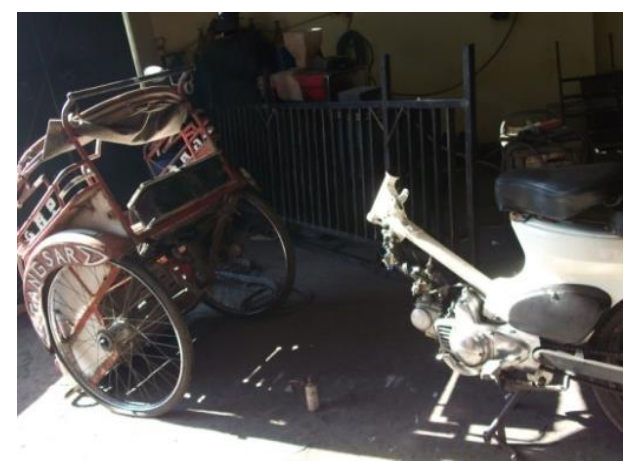

Gambar 1. Potongan becak-motor

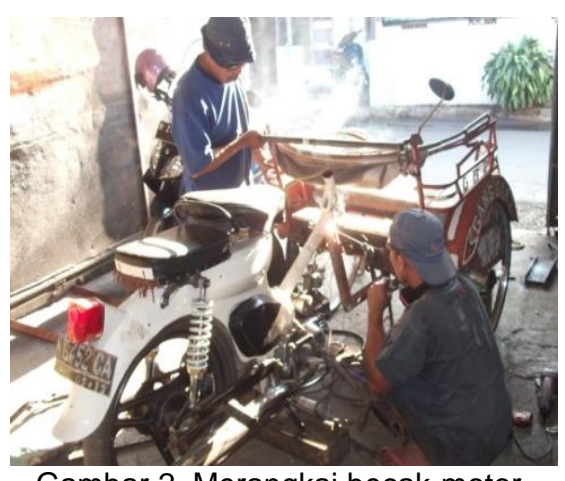

Gambar 2. Merangkai becak-motor

Tanaman untuk reboisasi adalah bibit nangka unggul dibeli dari perkebunan bibit Tunas Baru Mulyoagung, DAU, Malang. Kondisi kebun bibit seperti pada Gambar 4.

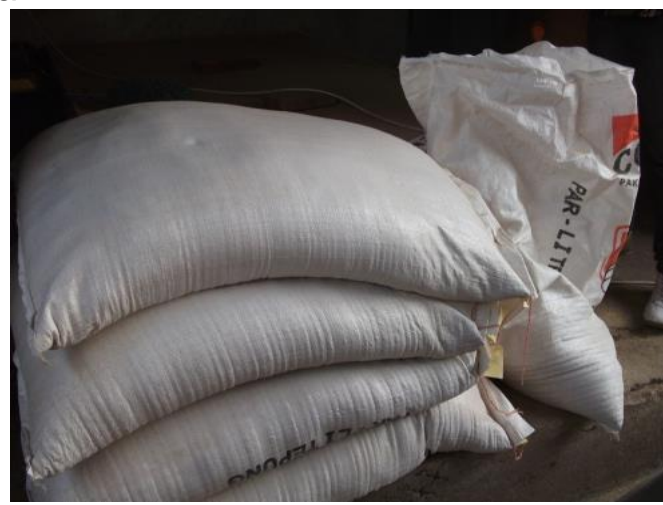

Gambar 3. Pengadaan pakan ayam 


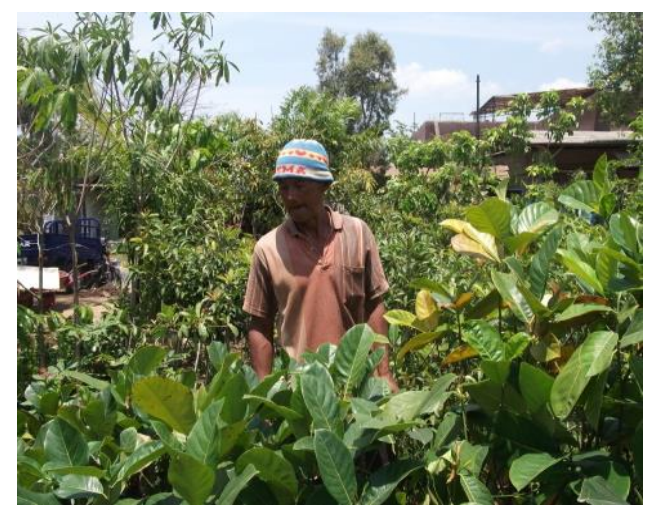

Gambar 4. Memilih bibit nangka

\section{Sosialisasi program dan reobservasi mitra usaha}

Kegiatan awal program IbM ini adalah membuat perijinan dan melakukan sosialisasi program, alhamdulillah kunjungan tim pengabdi direspon pemilik mitra usaha menyenangkan dan penuh kekeluargaan seperti terlihat pada Gambar 5.
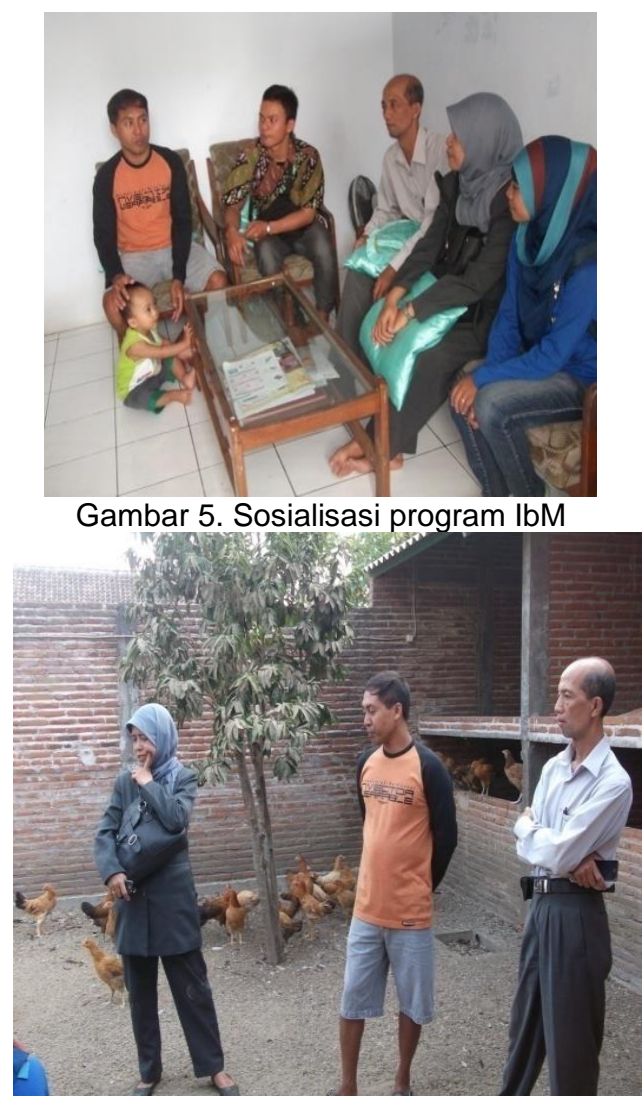

Gambar 6. Observasi kandang ayam 
Selanjutnya tim pengabdi melakukan reobservasi ke lokasi kandang peternakan ayam ternyata sudah diperluas menyamping kanan yang sementara menggunakan bangunan calon rumah tempat tinggal seperti pada Gambar 6. Hasil reobservasi tim pengabdi dapat menentukan beberapa prioritas permasalahan yang harus ditangani yaitu:

- Memperbaiki rasio pejantan betina dalam kandang pembibitan menjadi perbandingan 1 pejantandengan lebih 6-7 ekor betina

- Mengembangkan pola penetasan telur bibit dengan menambah jumlah mesin tetas dan memperbaiki manajemen operasional penetasan telur

- Pengadaan bahan pakan alternatif yang murah dari limbah warung nasi, rumah makan/ restoran terutama masakan kering bukan soto, rawon dan lain. Selain itu dapat menggunakan limbah agroindustri lokal yang difermentasi dahulu agar berkualitas dan aman

- Memformulasi dan pembuatan pakan konsentrat dan ransum complete feed yang bergizi tidak kalah dengan pakan komersiel.

- Strategi pemberian pakan yang mencukupi kebutuhan nutrien bagi ayam sesuai dengan fase pertumbuhan ayam.

- Manajemen kandang yang nyaman dan litter yang tidak bau amonia menyengat.

- Manajemen pemeliharaan fase starter dan finisher kurang tepat

- Program vaksinasi harus mengikuti pola yang benar sehingga terhindar timbulnya penyakit, dan memberikan vaksin pada waktu yang tepat.

- Pemanfaatan kotoran ayam untuk pembuatan kompos pupuk organik dan memanfaatkan limbah dari pemotongan ayam dan sisa pakan tercecer untuk pakan ikan lele yang terletak disamping tempat pemotongan ayam.

- Penanaman tanaman produktif seperti pohon nangka, pisang, alpokat, muris, mangga di sekitar kandang untuk reboisasi, kesegaran udara dan mendapatkan tambahan penghasilan.

- Perbaikan sistem pemasaran ayam hidup dan penjualan karkas ayam.

\section{Penyuluhan dan Pembinaan Produksi}

Dalam tahap ini, tim pengabdi mempersiapkan materi penyuluhan tentang teori penetasan dan pembibitan ayam, strategi pemberian pakan, manajemen pemeliharaan ayam, program vaksinasi dan pengobatan penyakit, penanganan karkas dan sistem pemasaran karkas ayam kampung.

Penetasan telur ayam, sebaiknya menggunakan telur fertil ukuran normal tidak terlalu kecil atau tidak besar dari kandang pembibitan dengan rasio jantan : betina $=1: 6$, temperatur dalam mesin tetas diatur pada awal penetasan suhu rendah menuju akhir penetasan ditingkatkan suhunya dari $22^{\circ} \mathrm{C}$ sampai $27^{\circ} \mathrm{C}$. Peternak breeder mempunyai pasangan ayam kampung sebagai grand parent stock (GPS ayam kampung belum di HAKI-kan) yang sudah dapat menciptakan indukan parent stok hasil trangenik (Gambar 9) 
yang mempunyai telur banyak dan sifat resesif yang berarti apabila indukan ini disilangkan dengan ayam pejantan unggul seperti ayam Bangkok, maka performan ayam final stok mengikuti ukuran tubuh pejantannya. Ayam kampung final stock umur sehari (DOC) dibesarkan oleh peternak binaan sampai dipanen (umur 3-4 bulan) dan boleh dipasarkan atau ditampung oleh breeder lagi (Gambar 10). Breeder ini juga memfasilitasi pemotongan ayam (RPA) yang menerima pesanan karkas ayam kampung segarsehingga banyak meninggalkan limbah isi perut ayam. Limbah organik ini dimanfaatkan sebagai pakan ikan lele setengah umur yang dapat meringankan biaya pakan ikan lele.Kolam ikan lele ini posisinya bersebelahan dengan RPA yang memudahkan pembuangan limbah pemotongan ayam bagian non karkas terutama usus ayam seperti pada Gambar 14.
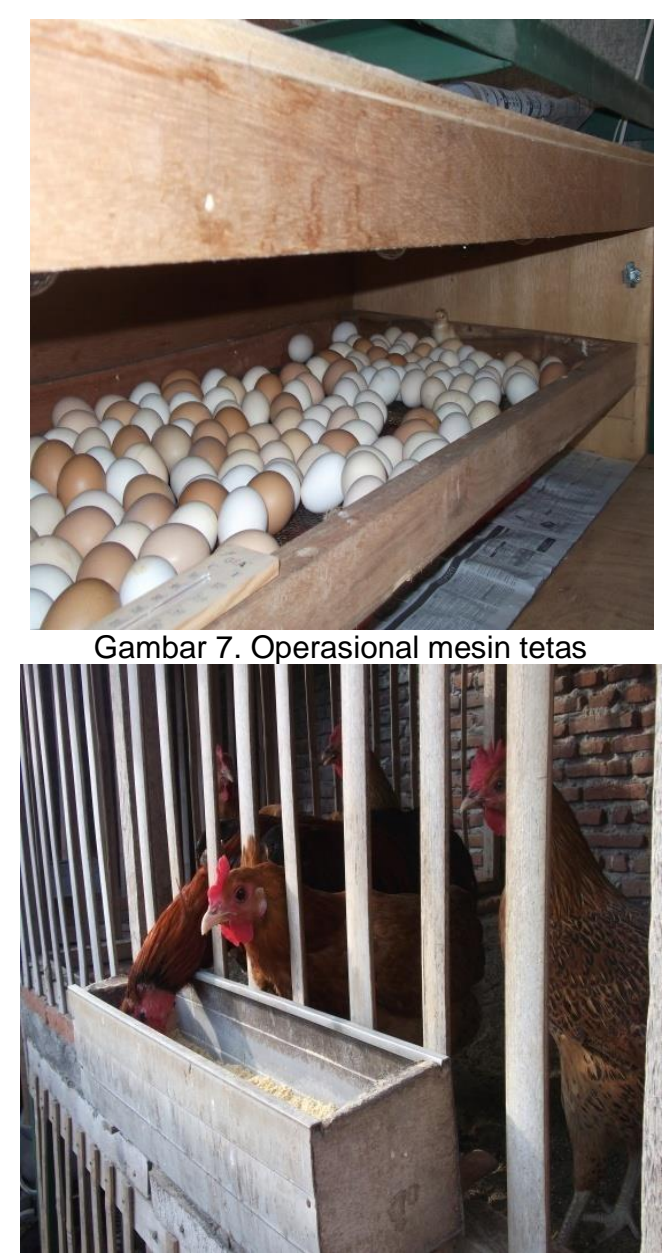

Gambar 8. Parent Stock ayam kampung 

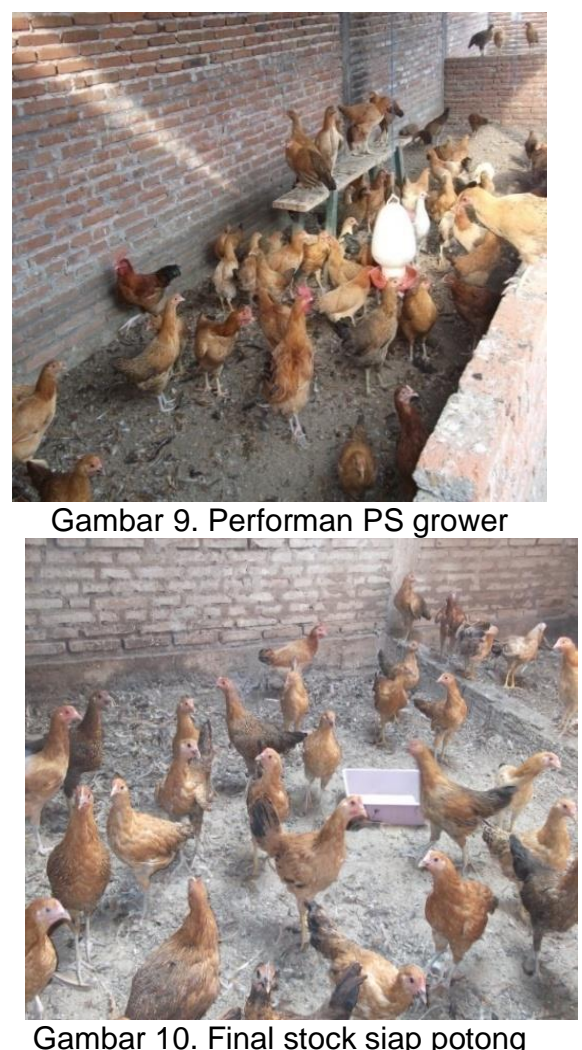

Dalam rangka menyongsong swasembada daging 2015 dari produksi unggas khususnya daging ayam buras, breeder ini sangat peduli dan mempunyai gagasan cemerlang yaitu pengembangan pola kemitraan ayam kampung dengan membentuk peternakan mandiri baru sebanyak-banyaknya sebagai breeder penyilangan parent stok, penetasan telur sendiri sekaligus pembesaran final stok sampai dipasarkan. Oleh karena itu tim pengabdi mendukung dan memberikan apresiasi gagasan itu dengan memberikan bantuan 2 mesin tetas dan pengadaan kandang layer bertingkat lantai dua digunakan untuk persilangan indukan parent stock dan pejantan ayam Bangkok. Kandang ini terbuat dari rangka kayu jawa, dinding belahan bambu dan menggunakan pasir campur sekam dengan kapasitas 5 - 8 ekor layer yang tidak permanen dan dapat dipindah-pindah, model kandang persilangan seperti pada Gambar 11, sedangkan model mesin tetas bertingkat atas bawah kapasitas per unit 500 butir telur bersekat rangka besi dengan sumber panas listrik dan janset seperti pada Gambar 12. 


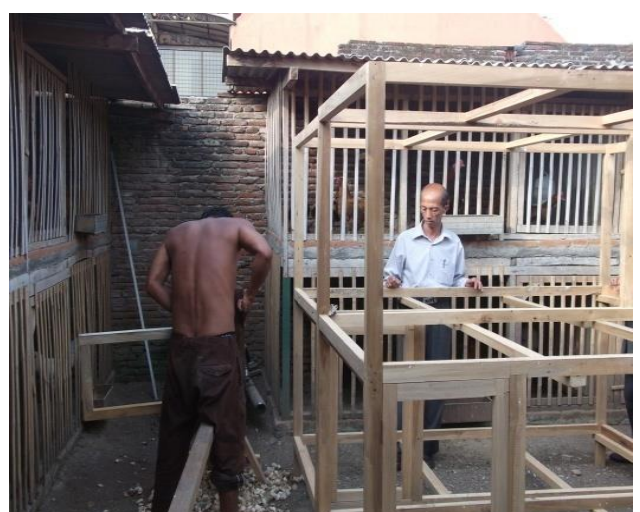

Gambar11. Pembuatan kandang PS

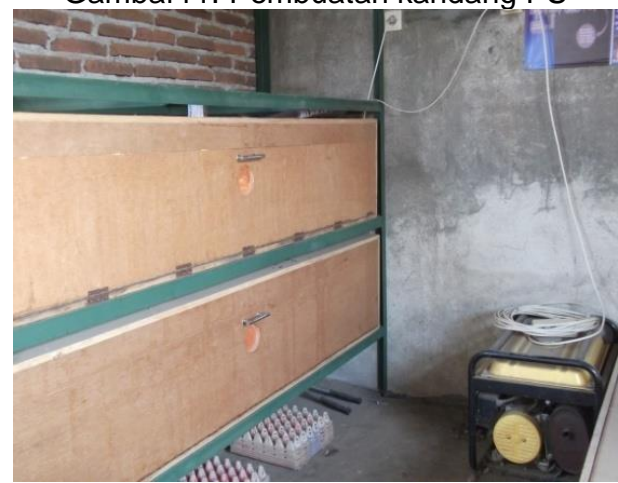

Gambar 12. Mesin tetas listrik/Jan set

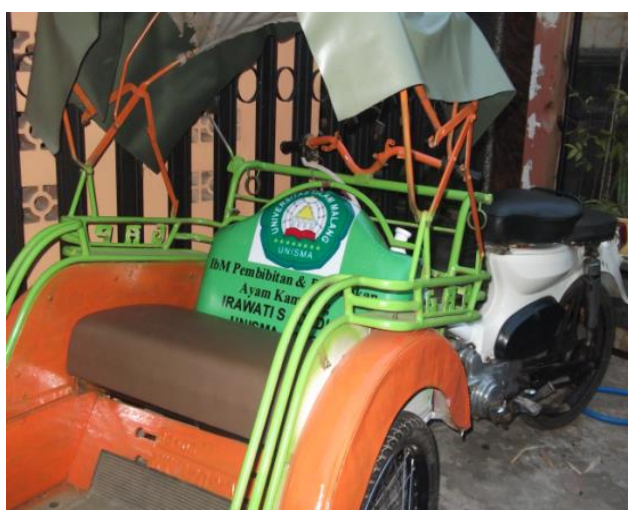

Gambar 13. Becak motor untuk peternak 


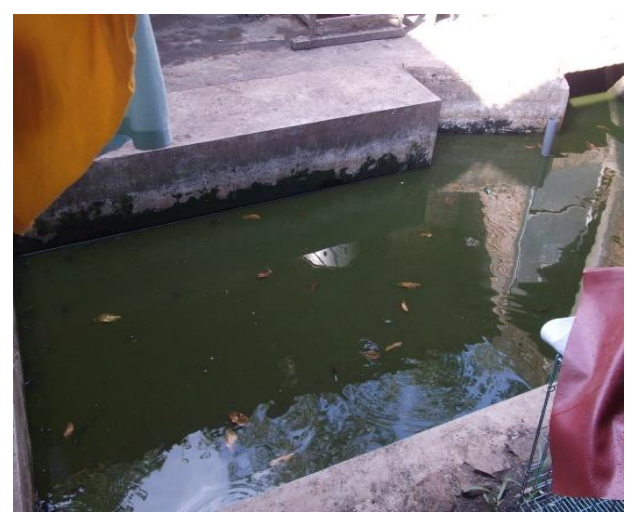

Gambar 14. Limbah viseral untuk lele

\section{Demoplot Fermentasi Pakan}

Fermentasi limbah agroindustri lokal terdiri dari kombinasi pakan komersial, gilingan jagung dan bekatul dalam kondisi kering udara dan dikombinasikan dalam perbndingan $70 \%$ : $10 \%$ dan $20 \%$ dengan menggunakan inokulan super campuran bakteri Laktobacillus acidiphilus, Saccharomyces cerevisease, Aspergillus oryzae, Bacillus subtillis dan Aspergillus niger sebanyak $10^{8} \mathrm{cfu} / \mathrm{gBK}$ bahan, diaduk manual sampai merata, kemudian campuran ini dimasukkan dalam sak polybeg ditutup rapat dan disimpan dalam kondisi kelembaban $60 \%$ dengan lama inkubasi 8 hari secara anaerob pada suhu ruang. Setelah fermentasi selesai, maka pakan fermentasi ini diambil sampel untuk dianalisis kandungan nutrien sebelum dan sesudah fermentasi. Mekanisme fermentasi pakan seperti disajikan Gambar 15.

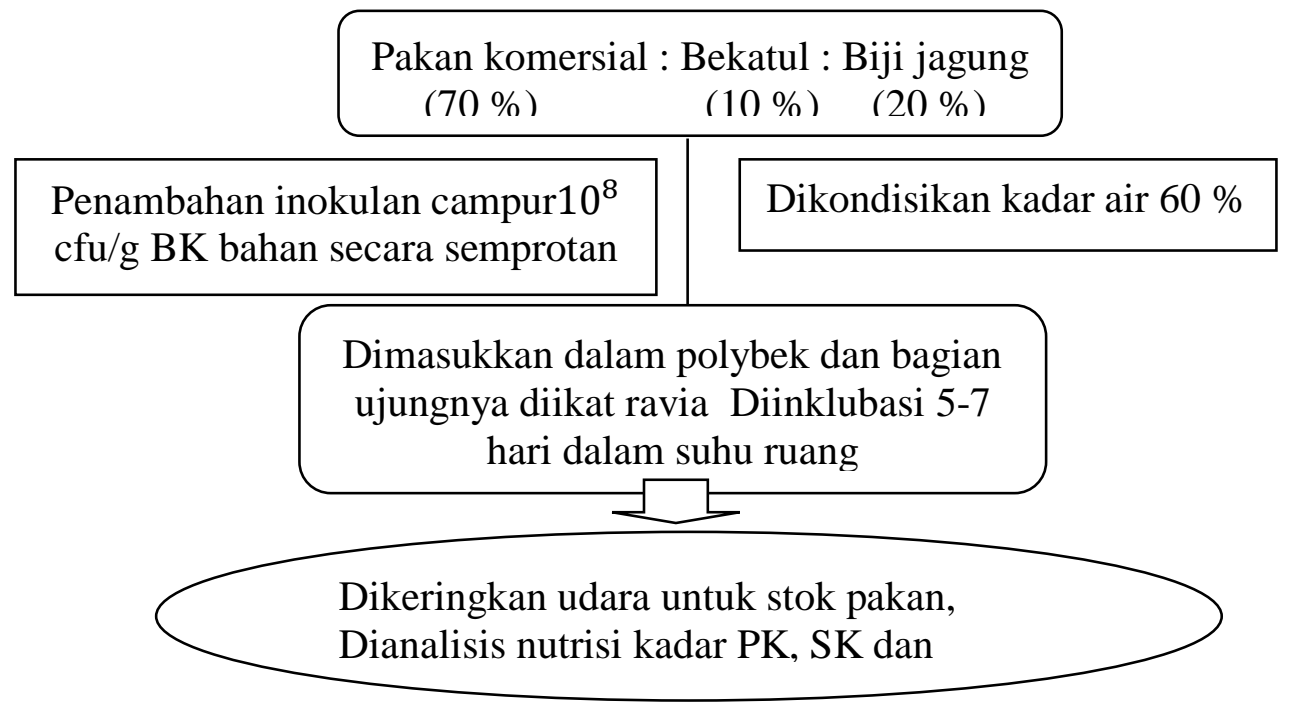

Gambar 15. Mekanisme fermentasi pakan ayam 
Produk pakan fermentasi ini dikeringkan matahari selama 2-3 hari sampai kadar air rendah menjadi kurang dari $15 \%$ sehingga pakan lebih awet, berkualitas, tidak mudah rusak dan dapat dibuat stok untuk memenuhi kebutuhan ayam selama kegiatan.

\section{Pengomposan Kotoran Ayam}

Ekskreta kotoran (feses) ayam sangat baik sebagai bahan baku untuk pembuatan pupuk organik, biasanya feses ini tercampur dengan pakan yang tercecer dan urin sehingga kandungan nutrisi terutama protein kasar (PK) cukup baik lebih $12 \%$. Secara fisik kotoran ayam lebih halus sehingga memudahkan dan mempercepat pengomposan menjadi pupuk organik yang berkualitas.

Tahapan dalam pembuatan kompos feses ayam yaitu pengumpulan feses dari litter kandang yang tercampur dengan sekam dan pasir, sebaiknya sekam dipisahkan dari feses, kemudian diaduk-aduk menggunakan sekrop dan ditambahkan mikroba pengurai (dekomposer) yang diberi air sampai membuat limbah feses berkelembaban $60 \%$ dengan cara digemborkan pada feses tersebut, lalu dimasukkan dalam sak woro dan diikat dengan tali ravia, selanjutnya diinkubasikan disimpan dalam suhu ruang selama 3-4 minggu.

Selanjutnya pengomposan diakhiri dengan membuka produk kompos dan mengeringkan menggunakan sinar matahari sampai kadar air $<12 \%$. Produk kompos ini dapat disimpan lebih lama dan dapat digunakan untuk pemupukan pada saat dibutuhkan sewaktu-waktu.

\section{Reboisasi Tanaman Pangan}

Lokasi kandang ayam terletak di dekat pemukiman penduduk yang padat sehingga lingkungan sekitar kandang perlu dihijaukan dengan tanaman pangan. Reboisasi yang menggunakan tanaman pangan seperti pohon nangka, pepaya dan mangga selain menghasilkan produk pokok buah, maka reboisasi ini bermanfaat menjadikan udara sehat, segar, asri dan naungan ayam dari panas matahari siang

Tujuan utama dilakukan reboisasi adalah membuat kondisi lingkungan sekitar kandang menjadi hijau berudara sehat, segar dan asri serta membuat tanah tidak gersang sekaligus peternak mendapatkan tambahan hasil panen tanaman pangan yang bisa dijual mendatangkan penghasilan. Kegiatan reboisasi dalam program IbM ini yaitu penanaman pohon nangka, pepaya dan mangga di sekitar kandang ayam, dimana pohon nangka bisa panen sepanjang tahun dan pohon mangga dan pepaya panennya musiman. 

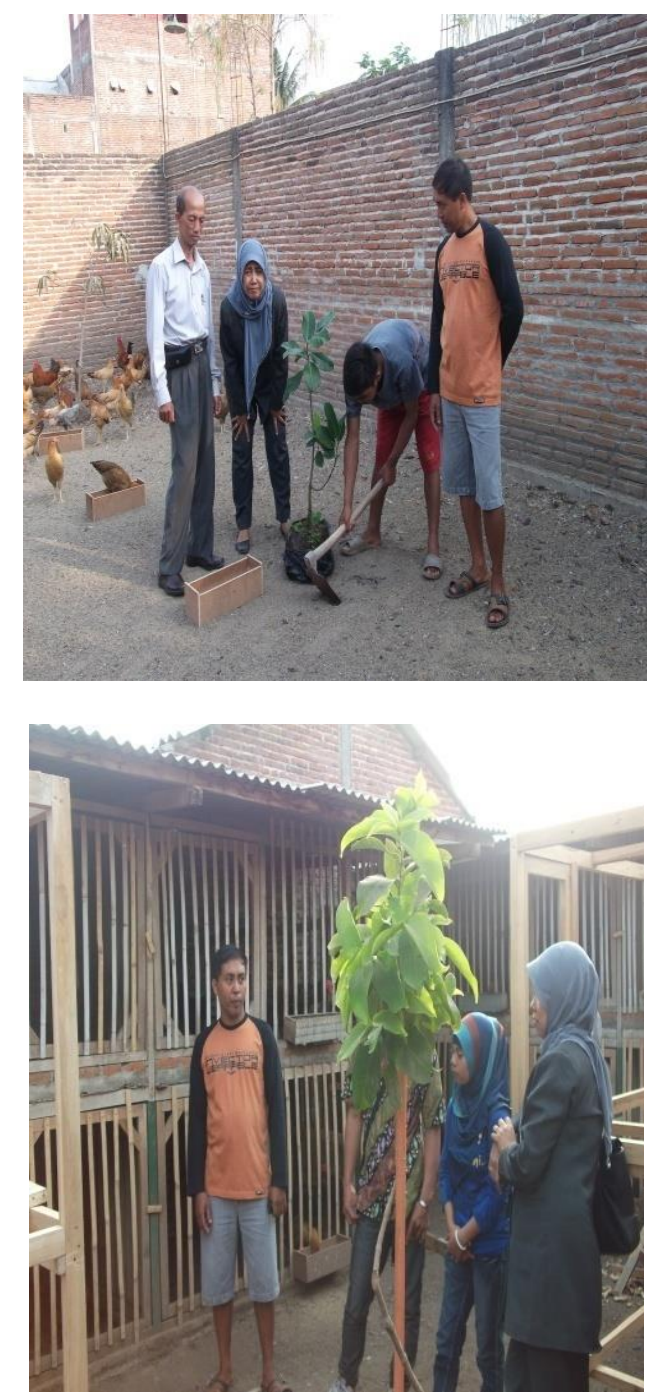

Gambar 16. Tanaman penghijauan lingkungan kandang ayam

\section{KESIMPULAN DAN SARAN}

\section{Kesimpulan}

Program IbM ini mendapatkan respon yang baik dari peternak untuk pembibitan dan pengendalian produksi ayam kampung. Pembibitan menggunakan grand parent stock ciptaan sendiri dengan perbandingan induk resesif dan pejantan Bangkok $5: 1$. Fertilitas telur baik dan daya tetas telur mencapai $94 \%$ Pemberian pakan menggunakan pakan komersial produksi Japfa Comfeed yang mahal dan fluktuatif yang selalu memberatkan peternak binaan, selain itu breeder selalu mengendalikan penyakit dengan melakukan vaksinasi secara terprogram. Pemasaran karkas ayam pada mesyarakat perumahan dan warung ayam jawa. 


\section{Saran}

Disarankan ada tindak lanjut pendampingan lebih intensif untuk meningkatkan kemampuan peternak binaan dalam manajemen produksi, strategi pemberian pakan, penanganan kesehatan dan sistem pemasaran menguntungkan.

\section{DAFTAR PUSTAKA}

Ensminger, M.E., J.E. Oldfield, and W.W. Heinemann. 1995. Feed and Nutrition. The Ensminger Publishing Company, California.

Mardikanto, T. 2009. Sistem Penyuluhan Pertanian. Pusat Pengembangan Agribisnis dan Perhutanan Sosial. Sebelas Maret University Press. Surakarta.

Rasyaf, M. 1994. Beternak Ayam Kampung. Penebar Swadaya. Jakarta

Tim Penyusun. 2013. Panduan Pelaksanaan Penelitian dan Pengabdian Kepada Masyarakat di Perguruan Tinggi. Edisi IX. Direktorat Penelitian dan Pengabdian Kepada Masyarakat, Direktorat Jendral Perguruan Tinggi, Kementrian Pendidikan dan Kebudayaan 